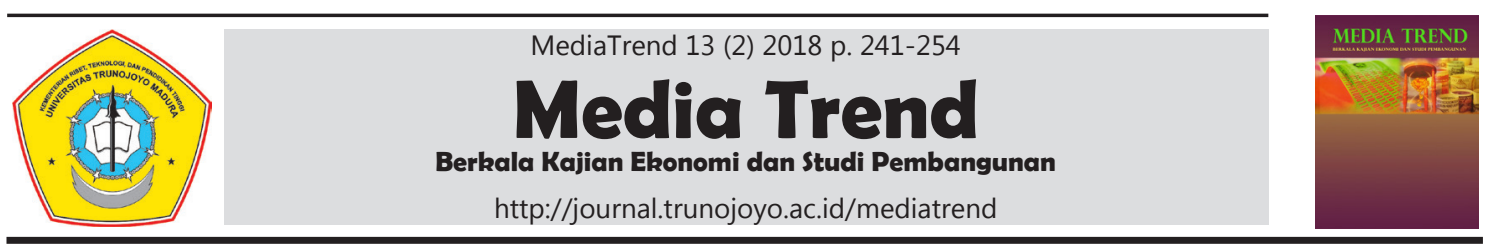

\title{
Penyerapan Tenaga Kerja Sektor Konstruksi di Indonesia (Studi pada 6 Provinsi di Jawa)
}

\author{
Herman Cahyo Diartho ${ }^{1^{*}}$, Ma'ruf Hanuraga ${ }^{2}$ \\ 1,2 Jurusan ilmu Ekonomi Studi Pembangunan, Fakultas Ekonomi dan Bisnis, Universitas Jember
}

\section{Informasi Artikel \\ Sejarah artikel: \\ Diterima September 2018 \\ Disetujui Oktober 2018 \\ Dipublikasikan Oktober 2018}

\section{Keywords:}

Province Minimum Wage,

Employment Absorption of

Construction Sector,

Panel Least Square (PLS)

\begin{abstract}
A B S T R A C T
Labor absorption can be measured by using the Provincial Minimum Wage (UMP) rate. The greater the value of wages earned is expected to affect the level of labor productivity. In this study aims to determine the effect of Province Minimum Wage on employment absorption of the construction sector. This research is qualitative and quantitative research. Qualitative analysis uses prescriptive analysis while quantitative analysis using method PanelLeast Square (PLS). The data used are time series (year 2006-2015) and cross section (6 provinces in Java). The type of data used in this study is secondary data obtained from the Central Statistic Agency (BPS) and the journal as a supporter. The analysis method used is linear regression analysis method of panel data with Random Effect Model (REM). The results show that, Minimum Wage variable Province has a positive influence with coefficient of 1.7671 and probability of 0.3538 to the absorption of labor in 6 provinces of Java Island in 2006-2015.
\end{abstract}




\section{Pendahuluan}

Upah dan tenaga kerja merupakan topik ekonomi yang terus menjadi bahan diskusi di kalangan ekonom dan peneliti. Pembatasan upah yakni, kebijakan upah minimum menjadi salah satu topik pembahasan di dalamnya. Peran upah minimum dalam pasar tenaga kerja dan perekonomian mendapat pandangan pro dan kontra baik secara teoritis maupun empiris (Herr, 2002; Kryriska dan Kopycinska, 2015). Secara teoritis, terdapat beberapa pandangan yang memperdebatkan hubungan antara upah minimum dan tenaga kerja. Pandangan ekonom Neoklasik menyatakan bahwa upah berperan penting terhadap pasar tenaga kerja, dimana upah ditentukan sama dengan produk marginal tenaga kerja (Bradley, 2007; Kryriska dan Kopycinska, 2015; Nikoloski, 2016). Pandangan tersebut menyatakan bahwa ketika upah dalam pasar tenaga kerja yang kompetitif mengalami kenaikan, maka kenaikan tersebut akan berdampak pada penurunan pada sisi permintaan tenaga kerja (Fletwood, 2016).

Bertolak belakang dengan teori tersebut, Keynes menyatakan bahwa upah bukan merupakan faktor kunci yang memengaruhi permintaan dan penawaran dalam pasar tenaga kerja, sehingga apa- bila terjadi kebijakan upah minimum dalam suatu perekonomian, maka hal tersebut kurang berpengaruh terhadap permintaan dan penawaran tenaga kerja. Sebangun dengan pemikiran Keynes, konsep segmentasi pasar tenaga kerja juga berpandangan bahwa dalam pasar tenaga kerja yang tersegmentasi, maka permintaan dan penawaran tenaga kerja tidak hanya dipengaruhi oleh tingkat upah, tetapi juga dipengaruhi oleh jenis pekerjaannya yang sesuai dengan segmen pasarnya (Jakstiene, 2010; Kumas, et al. 2014; Kryriska dan Kopycinska, 2015).

Upah minimum di Indonesia terus mengalami peningkatan dari waktu ke waktu (BPS, 2017). Gambar 1 menunjukkan variasi Upah Minimum Provinsi (UMP) enam Provinsi di Pulau Jawa. Berdasarkan Gambar tersebut, Upah Minimum Provinsi (UMP) dari ke enam Provinsi tersebut terus mengalami peningkatan dari tahun 2006 hingga tahun 2015, walaupun terdapat sebagian Provinsi yang mengalami penurunan UMP pada tahun 2015. Penerapan UMP tertinggi dimiliki oleh Provinsi Daerah Istimewa Yogyakarta. Kebutuhan kelayakan hidup dan inflasi merupakan faktor pentig yang timewa Yogyakarta tersebut (Merdekawaty, et al. 2016). Di sisi lain, Provinsi yang me-

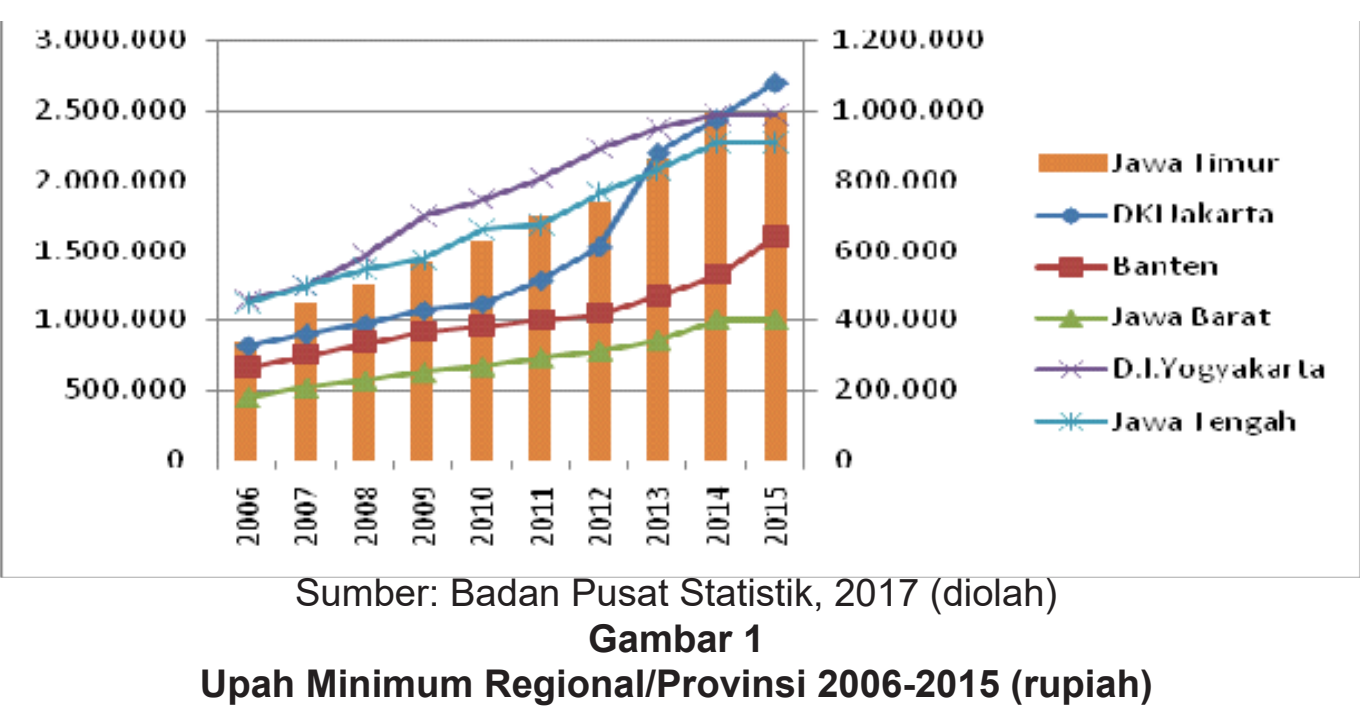


memengaruhi UMP di Provinsi Daerah Ismiliki tingkat UMP terendah berturut-turut dari tahun 2006 hingga tahun 2015 adalah Provinsi Jawab Barat. Selain itu, Provinsi Jakarta menunjukkan peningkatan UMP yang cukup signifikan dari tahun 2013 hingga mencapai tingkat UMP tertinggi di tahun 2015 dari lima Provinsi lainnya.

Infrastruktur merupakan faktor penting dalam pembangunan perekonomian. Keberadaan infrastruktur dalam perekonomian akan mendorong peningkatan produktivitas faktor-faktor produksi, memperlancar mobilitas penduduk, barang dan jasa, juga memperlancar perdagangan antar daerah. Ketersediaan infrastruktur akan meningkatkan output ekonomi dalam jangka pendek dan akan meningkatkan produktivitas dalam jangka panjang (Permana, 2010; Stupak, 2018). Pencapaian pembangunan infrastruktur tidak terlepas dengan tingkat profesionalitas pekerja dalam bidang tersebut (Adi dan Adillah, 2012).

Gambar 2 menunjukkan fluktuasi jumlah profesi tenaga ahli di perusahaan konstruksi pada enam Provinsi di Pulau Jawa. Jawa Barat merupakan Provinsi yang memiliki profesi tenaga ahli konstruksi tertinggi sejak tahun 2006 hingga tahun

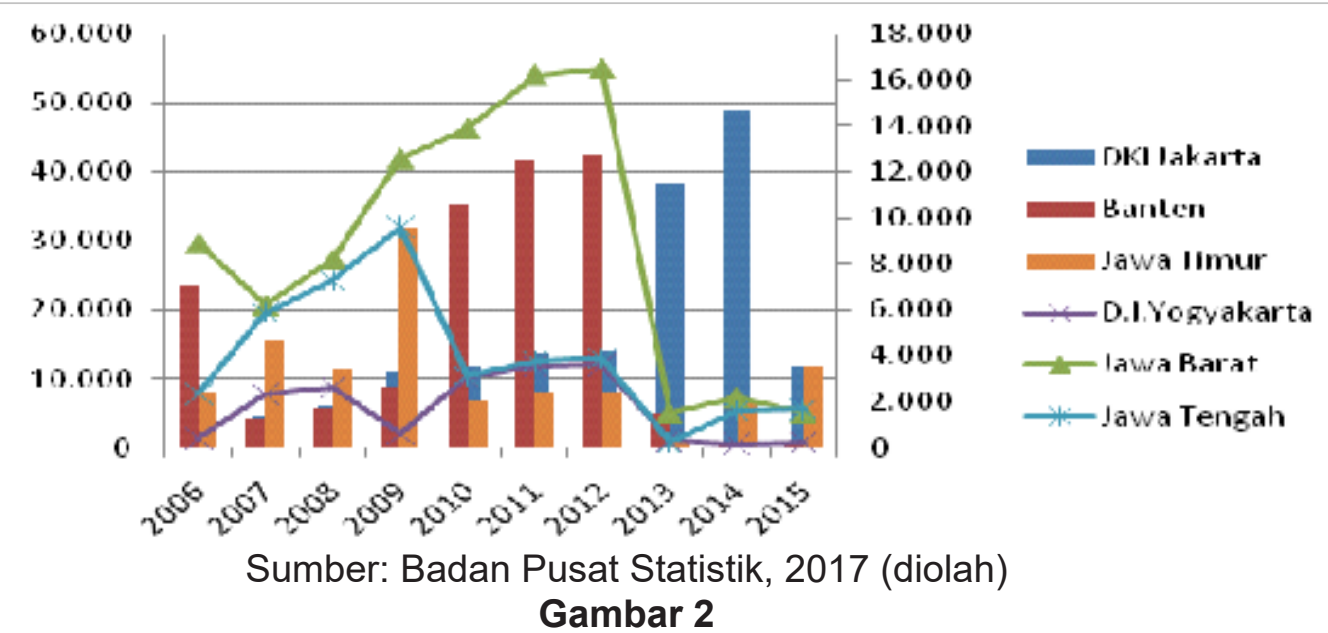

Profesi Tenaga Ahli di Perusahaan Konstruksi Menurut Provinsi di Pulau Jawa 2006-2015

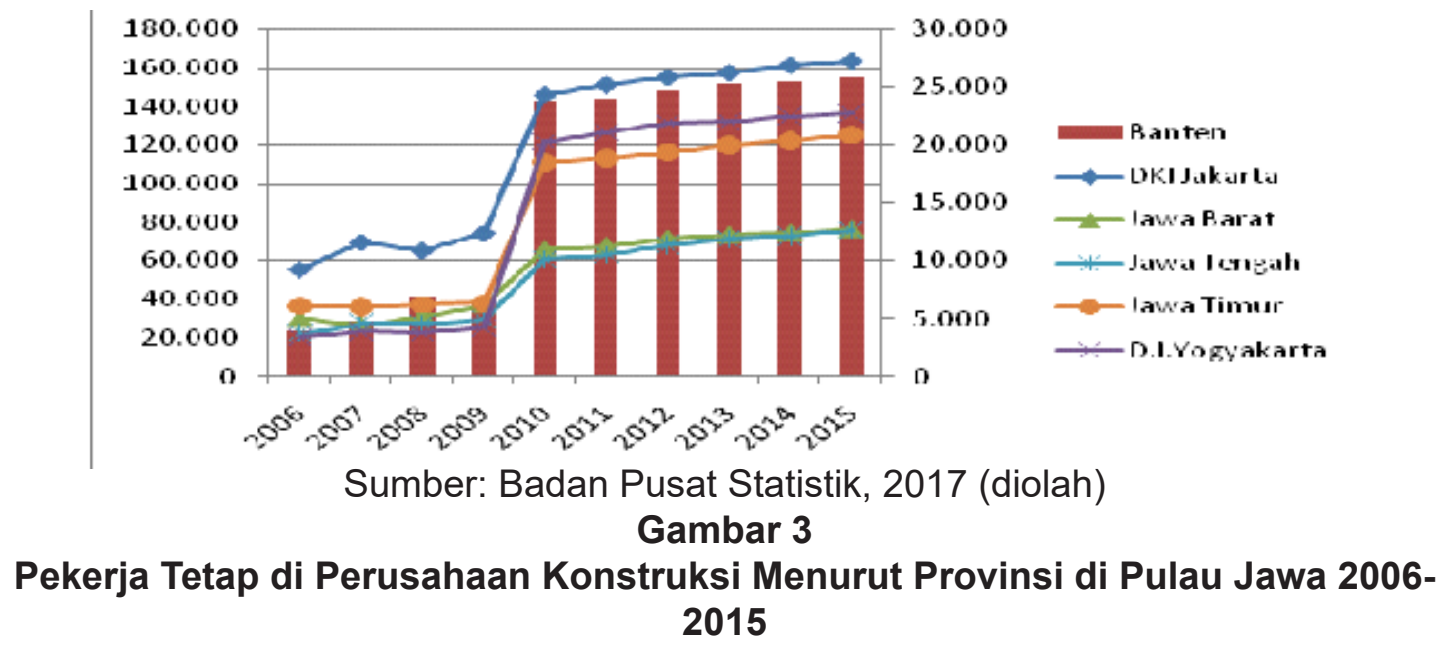


2012. Jumlah profesi tenaga ahli pada bidang konstruksi di Provinsi Jawa Barat kemudian mengalamipenurunan pada tahun 2013 hingga tahun 2015.

Pada sisi lain, Daerah Istimewa Yogyakarta (DIY) merupakan provinsi yang memiliki jumlah profesi tenaga ahli di bidang konstruksi terendah dari ke enam Provinsi di pulau Jawa. Apabila dilihat dari pertumbuhan profesi tenaga ahli di bidang konstruksi dari enam provinsi di Pulau Jawa, Daerah Khusus Ibu Kota (DKI) Jakarta merupakan provinsi yang memiliki pertumbuhan terbaik di antara lima Provinsi lainnya.

Gambar 3 menunjukkan dinamika atau pergerakan jumlah pekerja tetap perusahaan konstruksi pada enam Provinsi di Pulau Jawa. Berdasarkan Gambar 3, jumlah tenaga kerja tetap bidang konstruksi Provinsi DKI Jakarta menngalami fluktuasi pada tahun 2006 hingga tahun 2009. Namun demikian, DKI Jakarta merupakan Provinsi yang memiliki jumlah tenaga kerja tetap bidang konstruksi tertinggi dibanding dengan lima Provinsi lainnya. Sedangkan lima Provinsi lainnya, yakni Banten, Jawa Tengah, Jawa Barat, DIY, Jawa Timur memiliki jumlah tenaga kerja tetap bidang konstruksi yang cukup stabil pada tahun 2006 hingga tahun 2009. Kemudian, ke enam Provinsi tersebut mengalami peningkatan yang signifikan pada tahun 2010 hingga tahun 2015.

Pandangan-pandangan teoritis, empiris dan fenomena yang ada di Indonesia, pada dasarnya memiliki keterkaitan. Secara teoritis, penyerapan tanga kerja dapat dipengaruhi oleh beberapa faktor. Salah satu teori menyebutkan bahwa penyerapan tenaga kerja dapat dipengaruhi oleh tingkat upah pada daerah atau negara tersebut. Pandangan teoritis lain menyatakan bahwa penyerapan tenaga kerja tidak hanya dipengaruhi oleh upah, tetapi oleh kemampuan yang dimiliki oleh angkatan kerja dalam pasar tenaga kerja yang tersegmentasi. Begitu pula dari pandangan empiris juga memiliki pandangan yang saling bertolak belakang. Beberapa teori menyatakan bahwa perubahan tingkat upah tidak berpengaruh terhadap penyerapan tenaga kerja. Di samping itu, ada beberapa bukti kuat yang menunjukkan bahwa penerapan upah sangat berpengaruh terhadap penyerapan tenaga kerja. Kedua gap tersebut dapat dikaitkan dengan kondisi pasar tenaga kerja di Indonesia, khususnya bidang konstruksi, dimana tenaga kerja pada bidang tersebut dibayar sesuai dengan ketentuan upah minimum regional yang telah ditetapkan oleh pemerintah. Berdasarkan data yang telah dijelaskan pada paragraf sebelumnya, menunjukkan bahwa peningkatan upah minimum diikuti dengan peningkatan penyerapan tenaga kerja tetap pada bidang konstruksi dan diikuti pergerakan fluktuatif oleh penyerapan tenaga kerja ahli dan pekerja tetap bidang konstruksi pada enam Provinsi di Pulau Jawa. Fenomena tersebut pada akhirnya menjadi alasan yang melatarbelakangi terkait pengaruh Upah Minimum Provinsi (UMP) terhadap penyerapan tenaga kerja pada sektor konstruksi di pulau Jawa.

Berdasarkan uraian di atas, maka rumusan masalah dalam penelitian ini adalah Bagaimana perkembangan ketenagakerjaan dari ke enam provinsi di pulau Jawa?, Bagaimana pengaruh Upah Minimum Provinsi terhadap penyerapan tenaga kerja di pulau Jawa?. Kemudian tujuan yang ingin dicapai dari penelitian ini adalah untuk mengetahui perkembangan ketenagakerjaan dari ke enam provinsi di pulau Jawa dan untuk mengetahui pengaruh Upah Minimum Regional/Provinsi terhadap penyerapan tenaga kerja di pulau Jawa.

\section{Metodologi \\ Desain Penelitian}

Penelitian ini diawali dengan mencari data yang sesuai dengan judul atau tema yang diangkat, dimana dalam pene- 
litian ini mengambil tema untuk menganalisis adanya pengaruh upah minimum provinsi terhadap penyerapan tenaga kerja sektor konstruksi di Indonesia yang diambil yaitu 6 provinsi di pulau Jawa. Data yang diperoleh dari Badan Pusat Statistik (BPS) adalah data upah minimum provinsi tahun 2006 hingga 2010 dan data penduduk berumur 15 tahun ke atas yang bekerja menururt provinsi dan lapangan pekerjaan utama sektor konstruksi tahun 2006 hingga 2010.

Sebelum dilakukan pengujian model data panel dilakukan uji stasioneritas data yang menggunakan uji unit root Augmented Dickey-Fuller. Terdapat tiga tingkatan dalam pengujian ini yaitu level, first difference, dan second difference dengan kategori non intercept, dan trend intercept. Maksud dari tingkatan tersebut yaitu apabila data pada tingkat level belum stasioner maka dilanjutkan pada tingkat first difference, dan jika masih dirasa belum stasioner juga maka dilanjutkan pada tingkat second difference hingga data terstasionerkan pada tingkatan yang sama. Disarankan apabila data stasioner pada tingkat second difference dilakukan penambahan data karena kemungkinan hasil lebih besar. Setelah data stasioner, dilanjutkan dengan uji kointegrasi dengan tujuan untuk melihat ada tidaknya hubungan jangka panjang antar variabel.

Setelah melakukan uji stasioneritas dan kointegrasi tahap selanjutnya adalah mengestimasi model data panel yang dibagi menjadi tiga model yaitu Panel Least Square, Fixed Effect Model, dan Random Effect Model. Dalam memilih ketiga model tersebut digunakan pula tiga pengujian, diantaranya adalah uji Chow, uji Hausman, dan uji Lagrange Multiplier. Pengujian terakhir adalah uji asumsi klasik yang terbagi atas uji multikolinearitas, heteroskedastisitas, dan normalitas. Apabila semua tahap dalam pengujian telah terpenuhi, proses selanjutnya yang merupakan proses terakhir dari rangkaian pengujian adalah interpretasi dan justifikasi hasil.

\section{Jenis dan Sumber Data}

Penelitian ini dilakukan dengan mengumpulkan informasi penelitian, yang dikumpulkan melalui studi literature terhadap publikasi dari instansi terkait dan jurnal-jurnal ilmiah dan lainnya. Data yang digunakan dalam penelitian ini ialah data sekunder. Secara umum sumber data penelitian ini diperoleh dari Badan Pusat Statistik per provinsi di Pulau Jawa.

Data sekunder yang digunakan dalam penelitian ini : (1) Data Penduduk Berumur 15 Tahun Ke Atas yang Bekerja menurut Provinsi dan Lapangan Pekerjaan Utama Sektor Konstruksi tahun 2006 -2015, dan (2) Data Upah Minimum Provinsi tahun $2006-2015$

\section{Metode Analisis Data}

Metode Panel Least Square (PLS). Model ini dikenal dengan estimasi Common Effect yaitu teknik regresi yang paling sederhana untuk mengestimasi data panel dengan cara hanya mengkombinasikan data time series dan data cross section (Gujarati dan Porter, 2009). Model ini hanya menggabungkan kedua data tersebut tanpa melihat perbedaan antar waktu dan individu sehingga dapat dikatakan bahwa model ini sama halnya dengan metode OLS (Ordinary Least Square) karena menggunakan kuadrat kecil biasa. dimana TsK adalah Tenaga kerja sektor konstruksi, UMP adalah Upah Minimum Provinsi, a adalah Konstanta, i adalah Provinsi, t adalah Periode waktu, et adalah Variabel Penganggu

Dengan penggunaan data panel dalam penelitian ini, maka digunakan beberapa pendekatan metode teknik analisis. Pertama, Fixed Effect Model (FEM): pada pendekatan model efek tetap, diasumsikan bahwa intercept dan slope ( $\square$ ) dari persamaan regresi (model) dianggap konstan baik antar unit cross section maupun antar unit time series. Kedua, Random 
Effect Model (REM): dalam mengestimasi data panel melalui pendekatan FEM, variabel dummy menunjukkan ketidakpastian model yang digunakan. Untuk mengatasi masalah ini, digunakan variabel residual yang dikenal dengan pendekatan random effect model (REM).

Prosedur dalam pengujian Panel Least Square (PLS) dalam suatu penelitian, terdapat suatu urutan dimana pengujian tersebut guna mengetahui tujuan masingmasing pengujian terhadap data. Pengujian tersebut antara lain adalah; 1) Uji Stasioneritas Data, guna melihat fluktuasi sebuah data. Data dikatakan stasioner apabila memenuhi asumsi stasioneritas yakni data harus sesuai dengan syarat central limittheorem (CLTM). 2) Uji Kointegrasi, Variabel yang semuanya secara individu I(1) dan berbeda-beda akan menyimpang berasama. Untuk beberapa kombinasi linier dari satu kumpulan I(1) menjadi I(0) maka variabel dikatakan terkointegrasi. 3) Uji Chow, adalah uji yang digunakan untuk mengetahui apakah teknik regresi data panel lebih baik menggunakan fixed effect model atau common effect model dengan asumsi bahwa unit cross section memiliki perilaku yang cenderung sama tidaklah realistis dikarenakan unit cross section memiliki perilaku yang berbeda (Juanda dan Junaidi, 2012). 4) Uji Hausman merupakan pengujian statistik untuk memilih apakah model fixed effect atau model random ef- fect yang paling tepat digunakan dalam estimasi data panel. Uji Hausman memberikan sebuah penilaian menggunakan Chisquarestatistics. 5) Uji Lagrange Multiplier (LM) Uji Chow adalah uji yang digunakan untuk mengetahui apakah teknik regresi data panel lebih baik menggunakan fixed effect model atau common effect model dengan asumsi bahwa unit cross section memiliki perilaku yang cenderung sama tidaklah realistis dikarenakan unit cross section memiliki perilaku yang berbeda (Juanda dan Junaidi, 2012). Adapun beberapa uji asumsi klasik yang digunakan dalam penelitian ini, diantaranya : (1). Uji Multikolinieritas; (2). Uji Heterokedastisitas; dan (3). Uji Normalitas;

\section{Hasil dan Pembahasan \\ Hasil Analisis Statistik Deskriptif}

Pada bagian ini menjelaskan mengenai gambaran umum data penelitian yang digunakan. Pada penelitian ini variabel yang digunakan adalah tenaga kerja sektor konstruksi dan UMP tiap penyerapan tenaga kerja. Hasil analisis statistika deskriftif menggambarkan perilaku dari variabel yang digunakan.

Dalam Tabel 1 dijelaskan bahwa variabel TK konstruksi dan UMP memiliki daya saing yang digambarkan melalui interval nilai maksimum dan minimum. Nilai maksimum TK konstruksi sebesar 302760.0 sedangkan minimumnya

Tabel 1

Hasil Analisis Statistika Deskriptif Penyerapan Tenaga Kerja

\begin{tabular}{ccc}
\hline Analisis & TK.Konstruksi & UMP \\
\hline Mean & 41826.91 & -173.7963 \\
Median & 13850.50 & 567.5000 \\
Maximum & 302760.0 & 24354.00 \\
Minimum & -253540.0 & -37308.00 \\
Std.Deviasi & 105677.8 & 7634.421 \\
Obs. & 54 & 54 \\
\hline
\end{tabular}

Sumber : data diolah, 2018 
-253540.0 lalu nilai maksimum dari variabel UMP sebesar 24354.00 sedangkan minimumnya sebesar -37308.00. Persebaran data variabel dapat dilihat melalui mean dan standar deviasi. Jika dirasa kecil maka persebaran data tersebut kurang begitu baik.

\section{Analisis Panel Least Square (PLS)}

Analisis PLS digunakan untuk menjawab pertanyaan empiris dan yang kedua yaitu bagaimana upah minimum provinsi memiliki pengaruh terhadap penyerapan tenaga kerja di Pulau Jawa.

\section{Uji Stasioneritas}

Tabel 2 memaparkan bahwa hasil uji unit root untuk variabel TK dan UMP stasioner pada tingkat level, sedangkan TK stasioner pada tingkat first difference ( $1^{\text {st }}$ difference). Hal tersebut ditunjukkan dengan nilai probabilitas kurang dari alpha 5\% (0.05).

\section{Uji Kointegrasi}

Uji kointegrasi dalam penelitian ini dilakukan dengan menggunakan metode Johansen. Metode Johansen terdapat tiga level yaitu $1 \%, 5 \%$, dan $10 \%$.

Tabel 2

Hasil Uji Unit Root Data Panel (TK dan UMP)

\begin{tabular}{|c|c|c|c|c|}
\hline No. & Unit Root & Tingkat & Prob. TK & Prob. UMP \\
\hline \multirow[t]{2}{*}{1} & \multirow{2}{*}{ Levin, Lin, Chu, (LLC) } & Level & $0.9136^{\star}$ & 0.0101 \\
\hline & & 1st Difference & $0.0000^{\star}$ & $0.0000^{*}$ \\
\hline \multirow[t]{2}{*}{2} & \multirow{2}{*}{ Im Pesaran, Shim (IPS) } & Level & $0.9810^{\star}$ & 0.1698 \\
\hline & & 1st Difference & $0.0071^{*}$ & $0.0003^{*}$ \\
\hline \multirow[t]{2}{*}{3} & \multirow{2}{*}{ Augmented Dickey Fuller (ADF) } & Level & $0.9640^{\star}$ & 0.1945 \\
\hline & & 1st Difference & $0.0036^{\star}$ & $0.0003^{*}$ \\
\hline \multirow[t]{2}{*}{4} & \multirow{2}{*}{ Phillip Perron (PP) } & Level & $0.9747^{\star}$ & 0.4389 \\
\hline & & 1st Difference & $0.0000^{\star}$ & $0.0000^{*}$ \\
\hline
\end{tabular}

*: stasioner $5 \%$

Sumber : data diolah, 2018

Tabel 3

Hasil Uji Kointegrasi Data Panel

\begin{tabular}{cccc}
\hline Keterangan & Metode & Nilai ADF Stat & Kointegrasi \\
\hline Variabel & Pedroni & 0.5503 & Tidak Terkointegrasi \\
TK dan UMP & Kao & 0.0668 & Tidak Terkointegrasi \\
Enam provinsi & Fisher & 0.5045 & Tidak Terkointegrasi \\
\hline
\end{tabular}

Sumber : data diolah, 2018 


\section{Uji Panel Least Square (PLS)}

Hasil analisis model panel least square menunjukkan bahwa variabel independen memengaruhi variabel dependen sebesar $0.22 \%$. Hal ini dikarenakan nilai adjusted R2 sebesar 0.0022. Selanjutnya hasil analisis model fixed effect menunjukkan bahwa variabel independen memengaruhi variabel dependen sebesar $3 \%$ yang ditunjukkan oleh nilai adjusted R2 sebesar 0.0390. Sementara untuk model random effect pengaruh variabel independen terhadap variabel dependen sebesar $90 \%$, dengan nilai adjusted R2 sebesar 0.9036 . Seluruh model menunjukkan bahwa pengaruh variabel independen terhadap variabel dependen berpengaruh secara positif dan tidak signifikan, hal ini ditunjukkan dari nilai probabilitas $f$-statistic yang lebih dari $5 \%$ (0.05).
Tahap selanjutnya yaitu dengan membandingkan masing-masing model guna mengetahui model terbaik yang digunakan sebagai estimasi permodelan panel VAR. Hasil uji Chow dalam penelitian ini menunjukkan bahwa model terbaik adalah model Random Effect karena nilai probabilitas f-statistic diatas 5\% (0.05) yaitu sebesar 0.3638 . selanjutnya pada hasil uji Hausman model terbaik yang terpilih adalah Fixed Effect karena nilai probabilitas f-statistic dibawah 5\% (0.05) yaitu sebesar 0.0034 . Untuk mencari model terbaik antara Fixed Effect dan Random Effect maka pengujian terakhir digunakan uji Lagrange Multiplier (LM) dengan hasil model terbaik yang didapat adalah Random Effect karena nilai probabilitas $f$-statistic diatas $5 \%$ (0.05) yaitu sebesar 0.9933. oleh karena itu model yang terbaik digunakan adalah Random Effect Model (REM).

Tabel 4

Hasil Estimasi dan Pengujian Model PLS, FEM dan REM

\begin{tabular}{|c|c|c|c|c|}
\hline No. & Variabel & $\begin{array}{l}\text { Panel Least } \\
\text { Square (PLS) }\end{array}$ & $\begin{array}{l}\text { Fixed Effect } \\
\text { Model (FEM) }\end{array}$ & $\begin{array}{c}\text { Random Effect } \\
\text { Model (REM) }\end{array}$ \\
\hline \multirow[t]{2}{*}{1.} & C & $\begin{array}{c}42134.03 \\
(2.6334)\end{array}$ & $\begin{array}{c}755919.3 \\
(8.9501)\end{array}$ & $\begin{array}{l}672511.9 \\
(23.0265)\end{array}$ \\
\hline & & {$[0.0111]^{*}$} & {$[0.0000]^{*}$} & {$[0.0000]^{*}$} \\
\hline \multirow{3}{*}{2.} & & 1.7671 & -14.1494 & -2.6295 \\
\hline & UMP & $(0.9355)$ & $(-1.8436)$ & $(-0.9001)$ \\
\hline & & {$[0.3538]^{*}$} & {$[0.0703]^{*}$} & {$[0.3721]^{*}$} \\
\hline 3. & Adjusted R-Squared & -0.0022 & 0.0390 & 0.9036 \\
\hline 4. & F-statistic & 0.8803 & 3.3989 & 93.2533 \\
\hline 5. & Prob (F-statistic) & 0.3524 & 0.0703 & 0.0000 \\
\hline \multirow[t]{4}{*}{6.} & Uji Chow & & & \\
\hline & Statistic & 1.1795 & & \\
\hline & Probabilitas & 0.3335 & & \\
\hline & Prob (F-statistic) & 0.3638 & & \\
\hline \multirow[t]{4}{*}{7.} & Uji Hausman & & & \\
\hline & Chi-Sq. Statistic & & & 0.0556 \\
\hline & Probabilitas & & & 0.8135 \\
\hline & Prob (F-statistic) & & & 0.0034 \\
\hline \multirow[t]{4}{*}{8.} & Uji Lagrange Multiplier (LM) & & & \\
\hline & Cross-section one-side & & 7.04E-05 & \\
\hline & Breusech-Pagan & & 0.9933 & \\
\hline & Model Random Effect & & & \\
\hline \multirow[t]{3}{*}{9.} & & & 42134.03 & \\
\hline & $\mathrm{C}$ & & $(2.6334)$ & \\
\hline & & & {$[0.0111]$} & \\
\hline \multirow{3}{*}{10.} & & & 1.7671 & \\
\hline & UMP & & $(0.9355)$ & \\
\hline & & & {$[0.3538]$} & \\
\hline
\end{tabular}

Sumber : data diolah, 2018 
Setelah menentukan Random Effect Model (REM) sebagai model yang digunakan dalam metode PLS maka langkah selanjutnya yaitu mengestimasi model Random Effect. Hasil estimasi menunjukkan bahwa Upah Minimum Provinsi (UMP) berpengaruh positif dan tidak signifikan terhadap penyerapan tenaga kerja sektor konstruksi dibuktikan dengan koefisien sebesar 1.7671 dan nilai probabilitas sebesar 0.3538. Oleh karena itu apabila terjadi peningkatan UMP sebesar 1000 maka akan meningkatkan tenaga kerja sebesar 176 orang.

\section{Uji Asumsi Klasik}

Uji multikolinearitas digunakan untuk mengetahui ada tidaknya hubungan antara variabel independen dalam suatu model regresi. Apabila koefisien korelasi variabel yang bersangkutan nilainya terletak diluar batas penerimaan (critical value) maka koefisien korelasi bermakna dan terjadi multikolinearitas. Untuk mengetahui suatu variabel terkena multikolinearitas dapat digunakan suatu dasar keyakinan yaitu sebesar 0,8 . Apabila angka yang didapati lebih besar dari 0,8 maka variabel tersebut terkena multikolinearitas begitupun pula sebaliknya jika hasil yang diperoleh kurang dari 0,8 maka variabel tersebut tidak terkena multikolinearitas.Berdasarkan Tabel dibawah, hasil dari penelitian ini menunjukkan tidak adanya variabel yang terkena multikolinearitas karena angka dari setiap variabel kurang dari 0,8 .
Heteroskedastisitas merupakan permasalahan sebuah model regresi dimana nilai variance tidak minimum. Masalah tersebut muncul disebabkan oleh karakteristik dari data cross section yang memiliki objek lebih dari satu, sehingga masing-masing data pada objek yang berbeda juga dipengaruhi oleh Error Term yang berbeda. Kondisi tersebut berdampak pada persebaran data yang tidak teratur. Model regresi yang baik adalah model yang homokedastisitas (tidak terjadi heteroskedastisitas). Kriteria yang digunakan adalah nilai probabilitas semua variabel lebih besar dari pada nilai $(\alpha=0.05)$. Hasil pengujian dapat diketahui bahwa nilai probabilitas upah minimum provinsi sebesar 0.5432 dengan keseluruhan dianggap lebih besar dari nilai signifikansi yaitu 0,05, maka dapat disimpulkan tidak terjadi masalah heteroskedastisitas.

Uji normalitas bertujuan untuk menguji apakah dalam model regresi terdapat variabel pengganggu yang memiliki distribusi normal atau tidak. Dengan kata lain digunakan untuk mengetahui indikasi kenormalan data. Gujarati dan Porter (2009) menyatakan kelebihan dari data yang mengikuti distribusi normal yakni, nilai rerata dari Error Term bernilai nol. Pengaruh Error Term yang sangat kecil memiliki pengaruh besar terhadap hasil suatu regresi. Semakin kecil pengaruh Error Term maka akan semakin baik hasil regresi tersebut. Gujarati dan Porter (2009) juga menunjukkan keunggulan lain dari

Tabel 5

Hasil Uii Asumsi Klasik

\begin{tabular}{cccc}
\hline No. & Asumsi Klasik & Probabilitas & Hasil \\
\hline 1. & Multikolinieritas & 0.1260 & Tidak terasumsi klasik \\
\hline 2. & Normalitas & 0.2616 & Tidak terasumsi klasik \\
\hline 3. & Heteroskedastisitas & 0.5432 & Tidak terasumsi klasik \\
\hline
\end{tabular}

Sumber : data diolah, 2018 
data yang terdistribusi normal yaitu memiliki nilai variance minimum dan nilai covariance sama dengan nol. Data yang memiliki nilai dari variance minimum mengindikasikan bahwa Error Term dalam data tersebut memiliki sebaran yang sama (homokedastisitas). Sejalan dengan hal itu, data yang memiliki nilai covariance sama dengan nol, menunjukkan bahwa Error Term masingmasing variabel dalam model regresi tidak saling berhubungan. Oleh karenanya, distribusi normal sangat menentukan baik buruknya hasil sebuah regresi dalam penelitian. Dalam penelitian ini, untuk menguji apakah distribusi data normal atau tidak digunakan uji Jarque-Bera ( $\mathrm{J}-\mathrm{B}$ test). Adapun kriteria pengujian Jarque-Bera ( $J$ - $B$ test), antara lain : a) Bila nilai JB hitung $\geq$ nilai $\mathrm{X}^{2}$ Tabel atau nilai probabilitas J-B hitung $\leq$ nilai probabilitas $(a=5 \%)$, maka hipotesis yang menyatakan bahwa residual, error term adalah berdistribusi normal ditolak; b) Bila nilai JB hitung $\leq$ nilai $X^{2}$ Tabel atau nilai probabilitas J-B hitung $\geq$ nilai probabilitas $(a=5 \%)$, maka hipotesis yang menyatakan bahwa residual error term adalah berdistribusi normal diterima. Berdasarkan hasil uji normalitas, menunjukkan bahwa nilai Jarque-Bera sebesar 2.681247, dan nilai probabilitas sebesar 0.261682 lebih besar dari 0,05. Maka dapat dikatakan bahwa model tersebut berdistribusi normal.

\section{Pembahasan}

\section{Diskusi Pengaruh Upah Minimum Provinsi Terhadap Penyerapan Tenaga Kerja}

Upah dan tenaga kerja adalah sebuah pembahasan ekonomi yang terus menjadi suatu diskusi di kalangan ekonom dan peneliti. Pembatasan upah yang menjadi salah satu topik pembahasan di dalamnya yakni, kebijakan upah minimum. Peran upah minimum dalam pasar tenaga kerja dan perekonomian terjadi sebuah pandangan pro dan kontra baik secara teoritis maupun empiris (Herr, 2002; Kryriska dan Kopycinska, 2015).
Secara teoritis, terdapat beberapa pandangan yang memperdebatkan hubungan antara upah minimum dan tenaga kerja. Pandangan para ekonom Neoklasik menyatakan bahwa upah berperan penting terhadap pasar tenaga kerja, dimana upah ditentukan sama dengan produk marginal tenaga kerja (Bradley, 2007; Kryriska dan Kopycinska, 2015; Nikoloski, 2016). Pandangan tersebut menyatakan bahwa ketika upah dalam pasar tenaga kerja yang kompetitif mengalami kenaikan, maka kenaikan tersebut akan berdampak pada penurunan pada sisi permintaan tenaga kerja (Fletwood, 2016). Bertolak belakang dengan teori tersebut, Keynes mengemukakan bahwa upah bukan merupakan faktor kunci yang memengaruhi permintaan dan penawaran dalam pasar tenaga kerja, sehingga apabila terjadi suatu kebijakan upah minimum dalam suatu perekonomian, maka hal tersebut kurang berpengaruh terhadap permintaan dan penawaran tenaga kerja.

Kalangan peneliti juga berdiskusi dan mencoba mencari tahu peran upah minimum terhadap lapangan kerja dengan data dan fenomena yang ada dan yang terjadi pada objek penelitian. Eldring dan Alsos (2012) telah mencoba meneliti hubungan tersebut dengan objek beberapa negara di Benua Eropa, hasil penelitian menunjukkan bahwa peningkatan upah minimum menyebabkan penurunan nilai pada pekerja dengan upah rendah (lowquality), dan akan menyebabkan pengusaha menekan permintaan pada tenaga kerja melalui seleksi yang lebih ketat, sehingga tenaga kerja fresh graduate akan memliki peluang yang sangat kecil yang memiliki pengalaman kerja dan produktivitas yang rendah akan mengalami kesulitan mencari pekerjaan.

Sejalan dengan hal tersebut, Bishop (2018); Bodnar, dkk (2018) menekankan bahwa kenaikan upah minimum pada dasarnya tidak terlalu berpengaruh kepada masyarakat yang telah memiliki pe- 
kerjaan, namun sangat berpengaruh kepada para pencari kerja, sehingga kondisi tersebut mencerminkan bahwa kenaikan tersebut memiliki dampak negatif terhadap penyerapan tenaga kerja. Kontras dengan hasil tersebut, Hohberg dan Lay (2015); Menon dan Rodgers (2017); Vazquez, dkk (2017) justru menunjukkan hasil bahwa peningkatan upah minimum berpengaruh positif signifikan terhadap pekerja pada sektor formal dan sedikit berdampak negatif terhadap pekerja di sektor informal. Cengiz, dkk (2018) dengan objek yang berbeda juga menunjukkan hasil yang sama, bahwa penetapan upah minimum di Amerika Serikat hanya berpengaruh semu terhadap penurunan lapangan pekerjaan yang ditunjukkan dengan peningkatan lapangan pekerjaan dengan upah di atas upah minimum seiring penurunan lapangan pekerjaan yang diakibatkan dari penetapan upah minimum tersebut.

Peningkatan upah pekerja selain bertujuan untuk meningkatkan kesejahteraan para pekerja, juga sebagai alat untuk meningkatkan kualitas sumber daya manusia dalam pasar tenaga kerja. Peningkatan upah minimum akan menyebabkan kenaikan pada biaya produksi, untuk menghindari kerugian, maka produsen akan mempertahankan pekerja dengan kualitas tinggi dan memberhentikan pekerja dengan kualitas rendah. Selain itu, produsen akan lebih selektif dalam memilih calon pekerja baru. Hal tersebut akan mendorong peningkatan kualitas angkatan kerja. Dalam sebuah pembangunan proyek konstruksi infrastruktur dimana memerlukan tenaga kerja yang memadahi dan terkualifikasi secara tepat. Dengan program pembangunan dimana proyek konstruksi yang dilakukan pemerintah di setiap daerah di Jawa diharap dapat menyerap tenaga kerja secara efektif. Karena penyerapan tenaga kerja merupakan tolak ukur kesejahteraan manusia, karena dengan terserapnya tenaga kerja yang berimbang dengan pertumbuhan pen- duduk, akan menekankan angka pengangguran di Indonesia.

Analisis deskriptif variabel penelitian menunjukkan hasil yang sama dengan analisis menggunakan metode Panel Least Square (PLS). Upah Minimum Provinsi (UMP) berpengaruh positif terhadap penyerapan tenaga kerja. Maka hipotesis yang menyatakan bahwa tingkat penyerapan tenaga kerja berpengaruh positif diterima. Apabila upah minimum meningkat maka penyerapan tenaga kerja sektor konstruksi dapat dikatakan meningkat pula. Penelitian ini sesuai teori upah minimum yang dikemukakan oleh David Ricardo, bahwa tingkat upah yang diterima oleh tenaga kerja yang tidak memiliki keterampilan (unskilled worker) hanya dipengaruhi oleh kepentingan untuk menutup biaya hidup kebutuhan pekerja dan keluarganya. Jika tingkat upah naik diatas biaya hidup minimum pekerja, maka akan meningkatkan penawaran tenaga kerja dan akan menurunkan tingkat upah. Apabila tingkat upah berada di bawah biaya hidup minimum maka hal ini akan menurunkan kekuatan penawaran tenaga kerja (labor force). Dimana pada empirisnya tingkat upah sengat berpengaruh pada jenis pekerja dengan keahlian atau supervisor. Tetapi kurang berpengaruh kepada jenis pekerja yang tidak memiliki keterampilan atau hanya sebagai pelaksana saja.

Adanya kesamaan dengan penelitian yang dilakukan oleh Hanfer et al. Pada tahun 2016 dengan judul penelitian Wage on Employment: Meta-Analysis. Dalam penelitiannya dapat ditarik suatu kesimpulan dimana Upah minimum nasional tidak berpengaruh signifikan terhadap tenaga kerja namun, untuk sub-kelompok tertentu yang berbeda menunjukkan efek yang merugikan untuk beberapa kelompok pasar tenaga kerja, seperti karyawan paruh waktu. Dalam penelitian tersebut karyawan paruh waktu dianggap tidak memberikan pengaruh yang baik dalam 
tenaga kerja dan dianggap menunjukkan efek merugikan dalam penentuan upah minimum yang diberikan oleh tenaga kerja.

Penelitian ini sejalan dengan hasil penelitian yang dilakukan oleh Fachreza (2017) yang berjudul analisis penyerapan tenaga kerja sektor konstruksi di kabupaten/ kota provinsi Jawa Timur tahun 2011-2015 bahwauntuk variabel upah minimum memiliki pengaruh positif dengan nilai koefisien sebesar 0.376859 yang artinya setiap kenaikan upah minimum sebesar Rp $1 \%$ maka akan meningkatkan penyerapan tenaga kerja sebesar $0.38 \%$.Jumlah penyerapan tenaga kerja pada provinsi Jawa Timur pada tahun 2011 hingga tahun 2015 mengalami fluktuasi. Hal tersebut dikarenakan beberapa faktor yang dapat mempengaruhi penyerapan tenaga kerja yakni seperti tingkat upah, investasi daerah dan beberapa faktor lainnya. Upah minimum regional di provinsi Jawa Timur cenderung mengalami peningkatan. Penetapan upah minimum Kabupaten/Kota di Provinsi Jawa Timur tersebut didasarkan pada (KHM) kebutuhan Hidup Minimum. Upah minimum cenderung mengalami peningkatan setiap tahunnya sesuai dengan peningkatan kebutuhan hidup masyarakat.

Hal ini juga sesuai dengan penelitian Sumarsono (2003), upah akan mempengaruhi tinggi rendahnya biaya produksi yang dapat mengakibatkan pengurangan ataupun menambahan jumlah penggunaan atau penyerapan tenaga kerja. Penelitian ini memiliki hasil yang sejalan dengan hasil dari penelitian yang dilakukan Putra (2012) yang mengatakan "upah memiliki" pengaruh yang "positif signifikan" terhadap penyerapan tenaga kerja pada industri mebel di Kecamatan Pedurungan Kota Semarang. Fakta empris Nilai upah ratarata tenaga kerja pada perusahaan mebel di Kecamatan Pedurungan Kota Semarang tergolong masih rendah yaitu sebesar Rp.879.353,93. Upah tersebut dapat dikatakan rendah karena nilai upah minimum regional dikota Semarang sebesar
Rp.991.000, sehingga apabila keduanya dibandingkan maka upah tersebut terlihat rendah. Rendahnya tingkat upah rata-rata ini dikarenakan sebagian besar industri mebel di Kecamatan Pedurungan Kota Semarang ini merupakan industri dengan skala kecil hingga menengah. Tentu saja pemilik perusahaan tidak ingin merugi dengan adanya hal tersebut, sehingga pemilik perusahaan harus berani sedikit menaikkan harga jual produknya, yang tentu saja dengan harga yang masih terjangkau oleh masyarakat.

Namun berbeda dari hasil penelitian dari Zavodny (2000), dalam penelitiannya menganalisis mengenai adanya pengaruh upah minimum, jam kerja, dan tenaga kerja remaja menunjukan bahwa kenaikan upah minimum dapat menurunkan tingkat tenaga kerja tetapi tidak mempengaruhi jam kerja baik di kalangan remaja yang bekerja atau semua remaja. Hasil tingkat individu tidak menunjukkan bahwa kenaikan upah minimum memiliki dampak negatif yang signifikan pada jam kerja oleh upah rendah remaja yang kemungkinan akan terpengaruh oleh kenaikan upah minimum. Hasilnya menunjukkan bahwa tenaga kerja remaja dengan upah rendah cenderung tetap bekerja, relatif terhadap tenaga kerja remaja dengan upah tinggi, ketika upah minimum dinaikkan. Namun, efek buruk ini hilang ketika tenaga kerja remaja dengan upah rendah ini dibandingkan dengan tenaga kerja remaja upah rendah lainnya selama periode ketika upah minimum tidak meningkat.

Berbeda dengan penelitian yang dilakukan oleh Lang dan Kahn (1998). Dalam penelitiannya, Menunjukkan bahwa dalam hukum upah minimum terdapat persaingan yang semakin meningkat dari produktivitas tenaga kerja yang lebih tinggi sehingga membuat produktivitas tenaga kerja yang lebih rendah menjadi lebih buruk tanpa membuat produktivitas tenaga kerja yang lebih tinggi menjadi lebih baik. Kami memberikan bukti bahwa hukum upah minimum 
mengalihkan pekerjaan dari orang dewasa ke remaja dan siswa. Hal ini menimbulkan kekhawatiran tentang konsekuensi distribusi dari upah minimum bahkan ketika mereka meningkatkan pekerjaan.

\section{Simpulan}

Berdasarkan hasil analisis dan pembahasan yang telah dilakukan, maka dapat diambil kesimpulan sebagai berikut : Hasil analisis deskriptif pergerakan dinamika ketenagakerjaan pada ke enam provinsi di pulau Jawa antara lain: Provinsi DKI Jakarta, Banten, Jawa Barat, D.I.Yogyakarta, Jawa Tengah, dan Jawa Timur, menunjukkan tren peningkatan setiap tahunnya yaitu pada tahun 2006 hingga 2015 baik itu dalam konteks tenaga kerja konstruksinya ataupun upah minimumnya.Upah minimum provinsi berpengaruh positif terhadap penyerapan tenaga kerja tahun 2006-2015. Maka hipotesis yang menyatakan bahwa upah minimum provinsi berpengaruh positif diterima.

\section{Daftar Pustaka}

Adi, H.P dan Adillah, S.U. 2012. Sertifikasi Tenaga Kerja Konstruksi Sebagai Unsur Pendukung Pembangunan Infrastruktur. Universitas Islam Sultan Agung

Badan Pusat Statistik. 2017. Jumlah Pekerja Tetap Konsturksi Menurut Provinsi. BPS Indonesia. https://www.bps.go.id/[ Diakses pada Desember 2017].

Badan Pusat Statistik. 2017. Upah Minimum Provinsi. BPS Indonesia. https://www. bps.go.id/[Diakses pada Desember 2017].

Badan Pusat Statistik. 2017. Penduduk Berumur 15 Tahun Ke Atas Menurut Provinsi dan Jenis Kegiatan Selama Seminggu yang Lalu. BPS Indonesia. https://www.bps.go.id/[Diakses pada Desember 2017].

Bodnar, K., Fadejeva, L., Lordache, S., Malk, L., Paskaleva, D., Pesliakaite,
J., Jemec, N.T., Toth, P., Wyszyski, R. 2018. How do Firms Adjust to Rises in the Minimum Wage? Survey Evidence from Central and Eastern Europe. Working Paper Series, No. 2122.

Bradley, M.E. 2007. Efficiency Wages and Classical Wage Theory. Journal of the History of Economic Thought. Vol. 29. Halaman: 167 - 188.

Cengis, D., Dube, a., Linder, A., Zipperer, B. 2018. The Effect of Minimum Wages on Low - Wage Jobs: Evidence from the United States Using a Bunching Estimator. CEP Discussion Paper. No. 1531.

Eldring, L., Alsos, K. 2012. Europan Minimum Wage: A Nordic Outlook. Fafo Report. Vol. 16.

Fachreza, A. N. 2017. Analisis Penyerapan Tenaga Kerja Sektor Konstruksi di Kabupaten/Kota Provinsi Jawa Timur Tahun 2011-2015. Jurnal Ekonomi Pembangunan, Vol. 15, No. 2. Universitas Muhammadiyah Malang.

Fletwood, S. 2016. Reflection Upon Neoclassical Labour Economics. University of the West of England

Gujarati, D.N. dan D. C. Porter. 2009. Basic Econometrics. 5th ed. New York: McGraw-Hiil Irwin.

Hafner, M., Taylor, J., Pankowska P., Stepanek, M., Nataraj, S., dan Stolk, C. V. 2016. The Impact of the National Minimum Wage on Employment: A Meta-Analysis. Research Report RAND Europe, October, 1-38.

Herr, H. 2002. Wages, Employment and Prices. Working Papers of the Business Institute Berlin. No. 15

Hohberg, M., Lay, J. 2015. The Impact of Minimum Wages on Informal and Formal Labor Market Outcomes: Evidence from Indonesia. IZA Journal of Labor 
and Development, Vol. 4, No. 14.

Jakstiene, S. 2010. Labour Market Segmentation: Theoritical Aspect. Ekonomika ir Vadyba: Aktualijos ir Perspektyvos. Vol. 4, No. 20, Halaman: 53 - 63.

Juanda, B., Junaidi. 2012. Ekonometrika Deret Waktu: Teori dan Aplikasi. Bogor: IPB Press.

Kryriska, E., Kopycinska, D. 2015. Wages in Labour Market Theories. Folia Oeconomica Stetinensia.

Kumas, H., Caglar, A., Kataalp. H.S. 2014. Firm Size and Labour Market Segmentation Theory: Evidence from Turkish Micro Data. Procedia - Social and Behaviour Sciences. Vol. 150, Halaman: 360 - 373.

Lang, K dan Kahn, S. 1998. The Effect of Minimum-Wage Laws on The Distribution of Employment: Theory and Evidence. Journal of Public Economics 69 (1998) 67-82.

Merdekawaty, R., Ispriyanti, D., Sugito. 2016. Analisis Faktor-faktor yang Mempengaruhi Upah Minimum Kabupaten/Kota di provinsi Jawa Tengah menggunakan Model Spatial Autoregressive (SAR). Journal Gaussian, Vol. 5, No. 3, Halaman: $525-534$.

Menon, N dan Rodgers, Y. V. D. M. 2017. Child labor and the Minimum Wage: Evidence from India. Journal of Comparative Economics.

Putra, R. E. 2012. Pengaruh Nilai Investasi, Nilai Upah, dan Nilai Produksi Terhadap Penyerapan Tenaga Kerja Pada Industri Mebel di Kecamatan Pedurungan Kota Semarang. Economics Development Analysis Journal 1 (2) (2012).

Sumarsono, S. 2003. Ekonomi manajemen Sumber Daya Manusia dan Ketenagakerjaan. Yogyakarta: Graha IImu. 